of the DFG, Ernst-Ludwig Winnacker, sent her a congratulatory letter, reminding her of her last visit to the DFG in June, during which Bulmahn publicly pleaded for the implementation of a DM120 million (US\$72 million) program aimed at shortening the time between Ph.D. and professorship from the current nine years to five for investigators under the age of 30 . "There are clear expectations that federal and state governments will reach an agreement on financing the program soon," Winnacker wrote.

Detlev Ganten, director of the Max Delbrück Center (MDC) for Molecular Biology also echoes the importance of increased funding for young researchers and says that universities have in general been neglected by the federal government, which instead has invested heavily in the industrial biotechnology sector. He hopes that the new government will reverse the trend. Since 1990, GDP expenditure on science has decreased by one-fifth to 2.3 percent. Ganten suggests that three percent would be an appropriate level of funding, a recommendation endorsed by Hubert Markl, president of Germany's most prestigious research organization, the Max Planck Society.

Speaking as chairman of the Hermannvon-Helmholtz-Gemeinschaft Deutscher Forschungszentren, an umbrella organization of 16 research institutes with a combined workforce of 22,500, Ganten also pointed to persistent discrepancies that should be addressed within different parts of the country nine years after reunification: in former East-Germany only 118 people out of 100,000 work in $\mathrm{R} \& \mathrm{D}$, whereas the corresponding number for West Germany is 400 and more than 700 for the United States and Japan.

Many believe that environmental research and the development of alternative energy sources are the areas most likely to benefit under the new government. Instead, life sciences should be a priority, criticizes Harald zur Hausen, chairman of the German Cancer Research Center (DKFZ). At present, only 13 percent of the DM15 billion federal science budget is spent on this sector, says zur Hausen. In particular he wants to see a stronger commitment to genomic research. And that might well happen, but only with regard to its "ethical and legal consequences," according to the wording of the coalition treaty.

Michael Simm, OfFenburg

\title{
Research trio to develop new vaccines
}

With the announcement of grants to three British medical schools totalling $£ 850,000$, the pharmaceutical company Glaxo Wellcome (GW) has completed a unique three-way collaboration between government, industry and the academic world designed to carry out the basic research necessary to develop and produce new vaccines.

At the center of the collaboration is a new research institute, named after the vaccine pioneer Edward Jenner, which is located adjacent to the Institute of Animal Health in Compton, Berkshire. The three medical schools involved are at University College London, St George's Hospital, and the University of Glasgow.

GW has paid the $£ 10$ million costs of constructing and equipping the Jenner Institute. Half of the $£ 6$ million a year operating expenses, which include grants to outside research groups, are being provided by three government bodies: the Medical Research Council, the Biotechnology and Biological Sciences Research Council, and the Department of Health. GW has made a commitment to provide $£ 40$ million to the program over ten years-an important component of the company's strategy to expand its presence in the vaccine market-and the government commitment is similarly long-term.

In a dedication ceremony for the new building last month, Peter Mandeslon, Britain's Secretary of State for Trade and Industry, described the "unique arrangement" of the institute as an "excellent example" of the type of partnership between government and industry that is needed to enhance Britain's economic competitiveness. "It is important that we build on the strengths of academia and government research to exploit the strengths of the UK science base," he said.

Michael Elves of GW, who chairs the institute's board of directors, says that the basic approach to vaccines currently in use "has hardly advanced since Jenner's day." Elves explained, "we felt that we needed an institution capable of carrying out pretty fundamental research to study the immune response. Then, once you have understood the immune response you need, you can work out how to get it."

Three specific diseases, caused by HIV, respiratory syncitial virus (RSV) and the meningitis/pneumonia group, have been selected as initial targets for vaccine development research "because they each have generic lessons to teach us," according to Peter Bentley, scientific director of the institute. He explained that RSV, for example, is a mucosal pathogen that requires a basic understanding of lung immunology, while the HIV work involves setting up a viral immunology team.

The institute has already recruited 40 researchers out of a desired 60, to work on a wide range of projects, including autoimmunity, viral immunology, immunological memory, the role of dendtritic cells, carbohydrate immunology, lung immunology, and the major histocompatability complex.

Although the institute will own intellectual property generated through the research program, GW will have the first option to license, develop and market any potential products. The institute would receive royalty income from any such product.

DAVID Dickson, LONDON

\section{Brundtland continues WHO come-back campaign}

On her first visit to the US since taking charge of the World Health Organization (WHO) this summer, Gro Harlem Brundtland reinforced her ambition to bolster the WHO's international standing by meeting with some of the most senior American politicians and researchers.

During a visit to the White House she discussed new initiatives to fight tuberculosis and prevent the emergence of drugresistant strains with Hillary Rodham Clinton, Secretary of

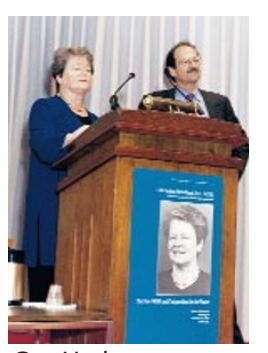

Gro Harlem Brundtland and Harold Varmus
Health Donna Shalala, and president of the World Bank, James Wolfensohn. And in the first visit by a WHO Director-General to the National Institutes of Health (NIH), Bruntland announced details of a multiagency, multi-program malaria initiative called Roll Back Malaria (RBM).

During her speech to NIH scientists and administrators, Brundtland said that as WHO's reorganization takes hold (Nature Med. 4, 992; 1998), it will be in position to direct 